\title{
KEY ENVIRONMENTAL CRITERIA ASSOCIATED WITH THE INVASION OF ANGUILLA AUSTRALIS GLASS EELS INTO ESTUARIES OF SOUTH-EASTERN AUSTRALIA.
}

\author{
L.J. MCKINNON (1) and G.J. GOOLEY (2)
}

Marine and Freshwater Resources Institute

(1) Kaiela Research Station, P.O. Box 1226, Shepparton 3632 Victoria, Australia.

(2) Snobs Creek Research Station, Private Bag 20, Alexandra 3714 Victoria, Australia.

\begin{abstract}
Sampling for glass eels of the shortfinned eel, Anguilla australis, was conducted in a number of estuaries in south-eastern Australia using glass eel and stow nets during the winter and spring months of 1994 and 1995. Preliminary modelling of the invasion of $A$. australis glass eels was undertaken by determining correlations between Catch Per Unit Effort (CPUE) of glass eels and water temperature, electrical conductivity, lunar phase and height of high tide. Low $(<10000 \mu \mathrm{S} / \mathrm{cm})$ electrical conductivity, medium $\left(10-14^{\circ} \mathrm{C}\right)$ water temperature and high ( $>0 \mathrm{~m}$ AHD) tide height showed significant correlation with high CPUE, but lunar phase (as moon age in days) did not. There appears to be some scope for predicting the invasion of $A$. australis glass eels into south-eastern Australian estuaries using temperature and electrical conductivity as key criteria for determining when glass eel fishing should commence. Such information is expected to contribute to the development of a commercial glass eel fishery in south-eastern Australia.
\end{abstract}

\section{PRINCIPAUX CRITĖRES ENVIRONNEMENTAUX ASSOCIÉS À L'INVASION DES CIVELLES DE ANGUILLA AUSTRALIS DANS LES ESTUAIRES DU SUD-EST AUSTRALIEN.}

\section{RÉSUMÉ}

L'échantillonnage des civelles de l'anguille "shortfinned", Anguilla australis, a été effectué dans plusieurs estuaires du sud-est Australien en utilisant des tamis à civelles au cours de l'hiver et du printemps de 1994 et 1995. Un modèle préliminaire de l'invasion des civelles de $A$. australis a été élaboré en utilisant les corrélations entre les Captures Par Unité d'Effort (CPUE) et la température moyenne de l'eau $\left(10-14^{\circ} \mathrm{C}\right.$ ), la conductivité $(10000 \mu \mathrm{S} / \mathrm{cm})$, la cote à marée haute $(>0 \mathrm{~m}$ AHD) et la phase lunaire (nombre de jours après la pleine lune). Les résultats montrent une corrélation significative entre les CPUE et la conductivité, la température moyenne de l'eau, et la hauteur de la marée haute. II n'y a pas de corrélation significative entre les CPUE et la phase lunaire. II semble que la possibilité de prédire l'invasion de civelles de $A$. australis dans le sud-est Australien en utilisant la température et la conductivité électrique comme critères pour déterminer quand la pêche des civelles devrait commencer pourrait être utilisée. Une telle information pourrait contribuer au développement commercial de la pêche des civelles dans le sud-est de l'Australie. 


\section{INTRODUCTION}

The shortfinned eel, Anguilla australis Richardson, supports a commercial fishery in south-eastern Australia of around 300-350 metric tonnes per annum on average, the majority of which is produced in the State of Victoria. Until recently, most $A$. australis production in Victoria has been from the extensive culture of brown elvers (sub-adult stock), which are primarily sourced from Tasmania, and stocked into natural waterbodies for ongrowing. Commercial elver harvesting in Tasmania during 1995 exceeded 5 tons from two sites, $700 \mathrm{~kg}$ of which were sold by public tender (F. RUWALD, Inland Fisheries Commission, Tasmania, pers. comm.). However, the use of such elvers for extensive culture seedstock in Victoria has recently declined, largely because of the increased costs and competition with Asian countries which have imported Australian elvers for intensive aquaculture.

In contrast, the culture of anguillid eels in Europe and Asia relies almost solely on the supply of glass eel seedstock from wild sources in the Northern Hemisphere, although the majority of these stocks are presently in decline (GUERAULT et al., 1991; MORIARTY, 1992 ; ANTUNES and WEBER, 1993). Presently, there is only limited commercial harvest of glass eels for aquaculture in Australia, but the potential for this is currently being investigated.

The natural distribution of $A$. australis occurs on the south-eastern coast of Australia (Figure 1) from $27^{\circ} S$ to $44^{\circ} S$ (BEUMER and SLOANE, 1990). A. australis are thought to spawn in the Coral Sea at about $350 \mathrm{~m}$, after which larval $A$. australis (leptocephali) drift down on the East Australian Current, metamorphose into glass eels and subsequently enter estuaries in south-eastern Australia between May and October inclusive (BEUMER and HARRINGTON, 1980).

The mechanisms of invasion and migration of glass eels of the genus Anguilla have been described in many countries (DEELDER, 1970; JELLYMAN, 1977, 1979; TESCH, 1977 ; MCCLEAVE and KLECKNER, 1982). Typically, the initial invasion by anguillid glass eels, including $A$. australis, into estuaries and their subsequent active upstream migration into freshwater habitats is facilitated by tidal movement, using flood tides and generally at night (CREUTZBERG, 1961 ; JELLYMAN, 1979 ; BEUMER and HARRINGTON, 1980 ; MCCLEAVE and KLECKNER, 1982 ; GASCUEL, 1986 ; MCCLEAVE and WIPPELHAUSER, 1987 ; MCCLEAVE et al., 1987). Specific observations on the invasion and migration of $A$. australis glass eels in Australian estuaries have been reported, including reference to distribution and abundance and suitability for aquaculture, by BEUMER and HARRINGTON (1980), BEUMER (1983a, b), SLOANE (1984) and BEUMER and SLOANE (1990).

For the purposes of this paper, glass eel invasion is defined as the flow-carried transport of unpigmented glass eels into and within the estuary, including flow-assisted migration via tidal bore, as opposed to the active swimming phase of upstream glass eel and pigmented elver migration, which is generally considered to commence at or near the upper limit of the tidal zone (JELLYMAN, 1979 ; SLOANE, 1984 ; GASCUEL, 1986).

Several environmental cues are thought to influence the invasion and migration patterns of anguillid glass eels. TOSI et al. (1990) concluded that salinity is the most important factor directing $A$. anguilla glass eels towards freshwater. TONGIORGI, TOSI and BALSAMO (1986) demonstrated that temperature, although not the sole cue, is an important factor in glass eel orientation as thermal gradients between fresh and sea water often exist, the direction of which depends on latitude. CHEN, CHEN and TZENG (1994) showed that a direct relationship exists between catches of $A$. japonica glass eels and rainfall, which consequently results in an indirect relationship between sea-water temperature and glass eel abundance in the commercial catch. However, the effect of 


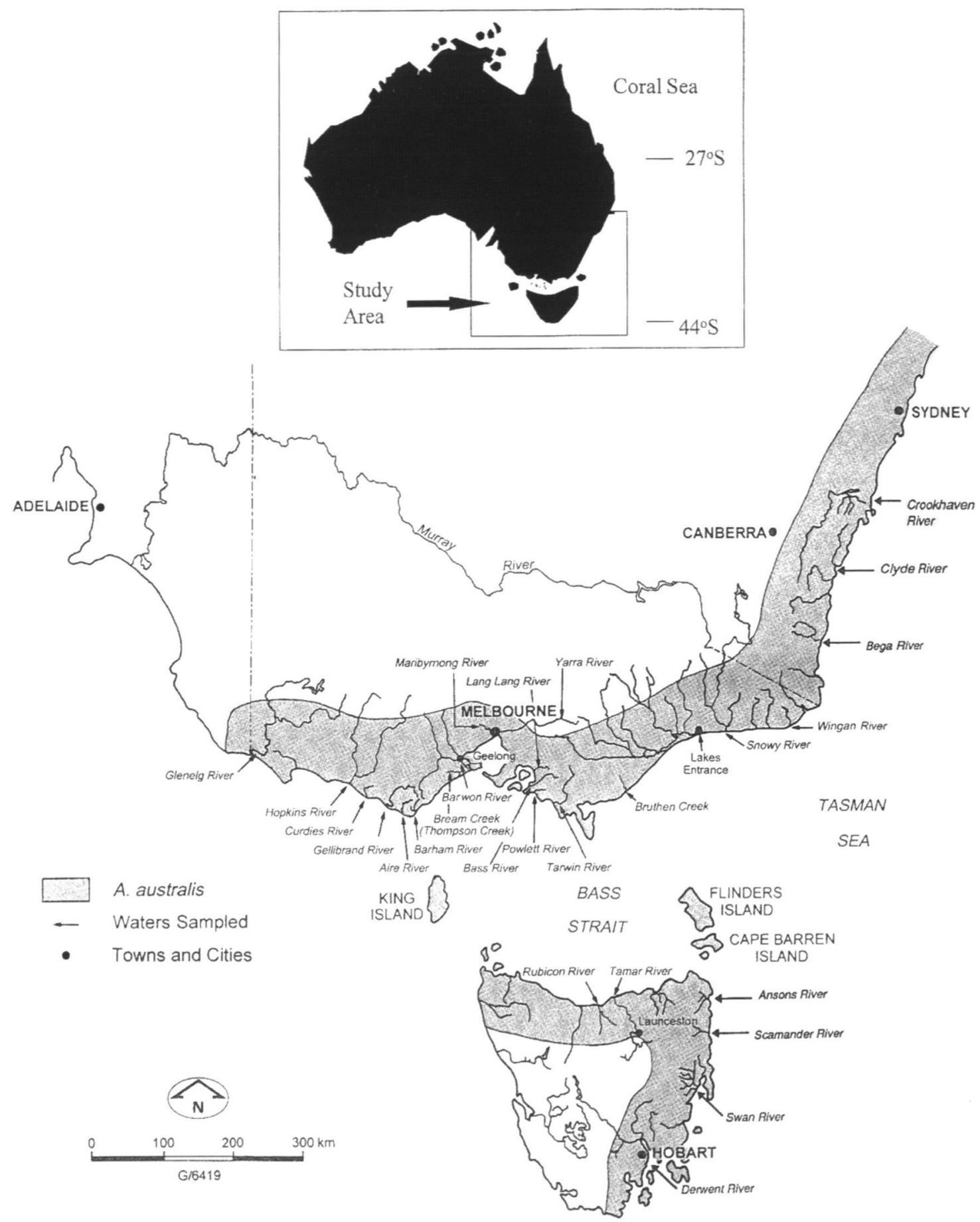

\section{Figure 1}

Distribution of Anguilla australis in south-eastern Australia ; sites indicated were sampled in 1994 and 1995.

\section{Figure 1}

Distribution de A. australis dans le sud-est de l'Australie ; les sites indiqués ont été échantillonnés en 1994 et 1995. 
rainfall on other environmental variables, such as decreased salinity, increased terrestrial runoff and increased flow, is also thought to confound the specific response of glass eels to temperature change (CHEN, CHEN and TZENG. 1994).

DOMINGOS (1992) demonstrated that glass eel abundance is favoured by high river flow and that rainfall increases the ascent of glass eels, although it was noted that heavy rainfall could have a negative effect on migration by producing river flows which are too high for successful upstream migration. It is considered that natural freshwater contains organic chemoattractants that act as cues for $A$. anguilla glass eels at sea to locate estuaries (CREUTZBERG, 1961). Such chemoattractants are thought to originate largely from decaying vegetation (SORENSEN, 1986) and from soil as chemical compounds which produce odours similar to that of geosmin (SOLA, 1995). The attraction of $A$. anguilla glass eels to organic chemicals has been found to be related to decreasing salinity (SOLA and TONGIORGI, 1996).

Glass eel invasion and migration in estuaries also appear to show a relationship with lunar phase, with many commercial glass eel fisheries operating only around new moon periods (e.g. ANTUNES, 1994). This is thought to be due to the effect of lunar phase on tidal magnitude, with the higher spring tides occurring at new moon and full moon (JELLYMAN, 1979).

In the present study, the invasion of $A$. australis glass eels into south-eastern Australian estuaries was investigated for the purpose of characterizing the primary environmental cues. With such information, it is considered possible to predict optimal fishing times by targeting the peak glass eel invasion phase. This investigation was part of an industry-funded project to assess the potential for the establishment and development of a commercial glass eel fishery, for seedstock for local commercial aquaculture production.

\section{MATERIAL AND METHODS}

Glass eel surveys were conducted in south-eastern Australian estuaries during the winter and spring (June-November) of 1994 and 1995. A total of 17 waters were sampled with glass eel nets in the first year, and 13 waters were sampled with both glass eel nets and stow nets in the second year (Figure 1).

Glass eel nets were $3 \mathrm{~m}$ in length, had two $3 \mathrm{~m}$ wings of $1 \mathrm{~m}$ drop attached, and were constructed of $2 \mathrm{~mm}$ nylon mesh. A detachable cod-end, constructed of $<0.5 \mathrm{~mm}$ mesh, was fitted to each net (Figure 2a). Glass eel nets were set in estuaries on either bank at dusk on a rising tide. Catch was cleared at regular intervals, usually hourly, until high slack water occurred and fishing ceased. Stow nets, also constructed of $2 \mathrm{~mm}$ mesh, were as described by WEBER (1986), with the exception that a $3 \mathrm{~m}$ cod-end was attached (Figure 2b). Stow nets were set in the main channel of the estuary at dusk on a rising tide and checked at regular intervals until high slack water occurred. Fishing generally occurred between 2-3 days before and 2-3 days following, new and full moons.

Catch was sorted using graduated screens $(10 \mathrm{~mm}, 2.5 \mathrm{~mm},<0.5 \mathrm{~mm})$. Glass eels collected in the bottom tray and, depending on quantity, were counted individually or enumerated by weighing the total catch and counting a known weight subsample. A subsample of 50 glass eels from each sampling period at each site was taken for individual lengths and weights to be recorded. 


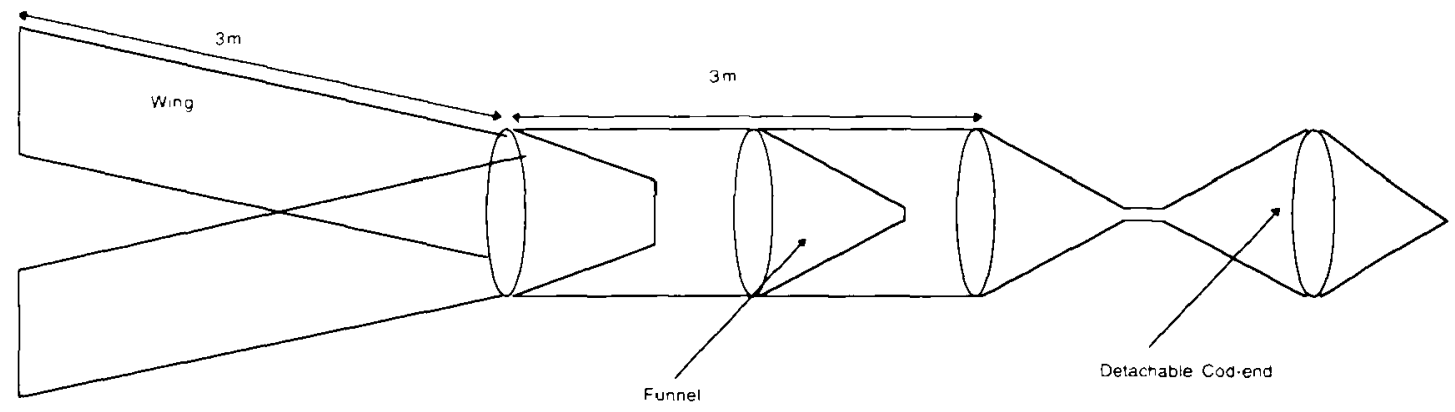

Figure 2a

Schematic plan of glass eel net.

Figure 2a

Plan schématique du filet à civelles.

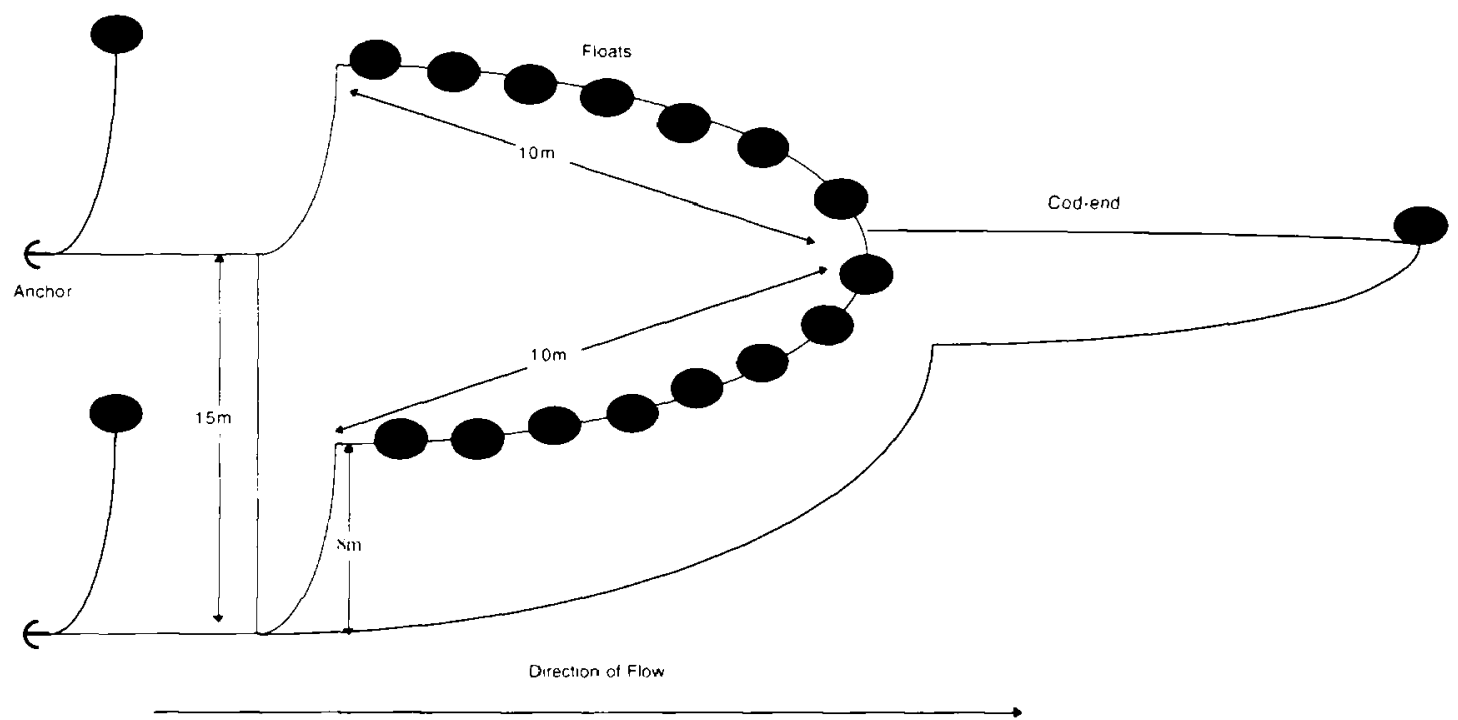

Figure 2b

Schematic plan of stow net.

\section{Figure 2b}

Plan schématique du filet "hamennet".

Environmental data collected from each sampling trip included water temperature and electrical conductivity, recorded at $15 \mathrm{~min}$. intervals using TPS 90FL Dataloggers throughout the sampling period, time and height of high water, mean stream discharge and lunar phase as the age of the moon in days.

For preliminary analysis, data from all samples at each site were pooled to improve sample size. Each variable was nominally divided into several levels which were typically encountered during glass eel surveys. These were : electrical conductivity (EC), "low", "medium" and "high" (0-10000, 10000-25000 and 25000-60000 $\mu \mathrm{S} / \mathrm{cm}$, respectively) ; temperature, "low", "medium" and "high" $\left(<10,10-14\right.$ and $>14^{\circ} \mathrm{C}$, respectively) ; moon age, "low", "medium" and "high" (0-10, 10-20 and 20-29 days old, respectively) and height of high tide, "low" and "high" ( $<0$ and $>0 \mathrm{~m}$ AHD (Australian Height Datum), respectively). Generalised Linear Modelling (GLM) Procedure (SAS/STAT Release 6.03 Edition) using Type III Sum of Squares was used to determine correlations between electrical 
conductivity, temperature, moon age and height of high tide and CPUE of glass eels (glass eels/net/hour) from three selected survey sites (with highest overall catch) : the Snowy, Tarwin and Tamar Rivers.

\section{RESULTS}

With the exception of moon age, each individual variable significantly correlated with CPUE of glass eels $(P<0.1)$ (Table 1 ), despite the high degree of variability of CPUE of glass eels between sampling sites (Table II) and within sites over time (e.g. Figure 3). Although CPUE generally reached a peak at each site following a new or full moon, i.e. moon age appears to correlate with CPUE (Figures 3 and 4), this relationship is not significant (Table I). Interactions between electrical conductivity and temperature, electrical conductivity and moon age, and temperature and moon age significantly correlated with CPUE of glass eels (Table I). Indeed, preliminary analysis indicates that overall, CPUE was significantly greatest when low electrical conductivity $(<10000 \mu \mathrm{S} / \mathrm{cm})$ and medium temperature $\left(10-14^{\circ} \mathrm{C}\right)$ coincided $\left(F_{18.88}=6.48, P<0.0005, R^{2}=0.63\right)$, although CPUE was also high when medium temperature occurred with low and high moon age, and when low salinity occurred with low and high moon age (Figure 4). High tides of higher maximum height, i.e. tides with relatively high water mark, showed a significant relationship with increased CPUE $(P<0.1)$, but this was not the case when combined with electrical conductivity, temperature or moon age (Table I).

\section{Table I}

Analysis of variance of Catch Per Unit Effort (CPUE) of A. australis glass eels in response to selected environmental variables.

\section{Tableau I}

Analyse de variance des Captures Par Unité d'Effort (CPUE) des civelles de A. australis par rapport aux variables environnementales choisies.

\begin{tabular}{llll}
\hline Source & df & $F$ & $P$ \\
\hline EC (Electric Conductivity) & 2 & 3.04 & $0.0542^{\star}$ \\
Temperature & 2 & 5.29 & $0.0072^{\star}$ \\
Moon Age & 2 & 0.13 & 0.8770 \\
Tide Height & 1 & 3.63 & $0.0607^{\star}$ \\
EC x Temperature & 2 & 4.80 & $0.0111^{\star}$ \\
EC $\times$ Moon Age & 3 & 3.47 & $0.0207^{\star}$ \\
EC $\times$ Tide Height & 2 & 0.20 & 0.8202 \\
Temperature $\times$ Moon Age & 2 & 8.53 & $0.0005^{\star}$ \\
Temperature $\times$ Tide Height & 1 & 1.05 & 0.3080 \\
Moon Age $\times$ Tide Height & 1 & 0.50 & 0.4829 \\
\hline
\end{tabular}

\footnotetext{
* Significant at $P<0.1$ level
} 


\section{Table II}

Catch Per Unit Effort (No. glass eels per net per hour) of Anguilla australis glass eels for 1994-95; GEN = glass eel nets ; SN = stow nets.

\section{Tableau II}

Captures Par Unité d'Effort (nombre de civelles / filet / heure) des civelles de A. australis pour 1994-95 ; GEN = filets à civelles ; SN = filets "hamennet".

\begin{tabular}{|c|c|c|c|}
\hline Site (East-West) & Date & Method & Mean CPUE \\
\hline Wingan $\mathrm{R}$ & $7-8 / 8 / 94$ & GEN & 11.1 \\
\hline Snowy R & $22-23 / 8 / 94$ & GEN & 57.7 \\
\hline Lakes Entrance & $21 / 8 / 94$ & GEN & 0.3 \\
\hline Bruthen Ck & $15-16 / 9 / 94$ & GEN & 1.3 \\
\hline Tarwin R & $17-18 / 8 / 94$ & GEN & 13.5 \\
\hline $\begin{array}{l}\text { Yarra R } \\
\text { Barwon R }\end{array}$ & $\begin{array}{l}9-13 / 10 / 94 \\
3-6 / 9 / 94\end{array}$ & $\begin{array}{l}\text { GEN } \\
\text { GEN }\end{array}$ & $\begin{array}{l}0.5 \\
25.0\end{array}$ \\
\hline Bream Ck & $\begin{array}{l}28- \\
29 / 10 / 94\end{array}$ & GEN & 0.1 \\
\hline Barham R & $12-13 / 9 / 94$ & GEN & 4.8 \\
\hline Aire R & $11 \& 14 / 9 / 94$ & GEN & 0.3 \\
\hline Gellibrand R & $5-9 / 9 / 94$ & GEN & 2.5 \\
\hline Curdies R & $15-19 / 9 / 94$ & GEN & 3.9 \\
\hline Hopkins R & $17-18 / 9 / 94$ & GEN & 0.1 \\
\hline Fitzroy R & 19/9/94 & GEN & 0 \\
\hline Glenelg R & $17 / 9 / 94$ & GEN & 0 \\
\hline Tamar R & $19 / 10 / 94$ & GEN & 55.5 \\
\hline Rubicon R & $\begin{array}{l}17- \\
18 / 10 / 94\end{array}$ & GEN & 1.5 \\
\hline Crookhaven $\mathrm{R}$ & $7-10 / 6 / 95$ & $\begin{array}{l}\text { SN } \\
\text { GEN }\end{array}$ & $\begin{array}{l}6.2 \\
0.6\end{array}$ \\
\hline Clyde R & $23 / 6-1 / 7 / 95$ & $\begin{array}{l}S N \\
\text { GEN }\end{array}$ & $\begin{array}{l}21.3 \\
7.5\end{array}$ \\
\hline Bega R & $3-5 / 7 / 95$ & GEN & 3.39 \\
\hline Bemm R & $15-19 / 7 / 95$ & $\begin{array}{l}\text { SN } \\
\text { GEN }\end{array}$ & $\begin{array}{l}118.9 \\
11.9\end{array}$ \\
\hline Snowy R & $12-16 / 8 / 95$ & $\begin{array}{l}\text { SN } \\
\text { GEN }\end{array}$ & $\begin{array}{l}669.4 \\
5.6\end{array}$ \\
\hline Tarwin $\mathbf{R}$ & $24-31 / 8 / 95$ & $\begin{array}{l}\text { SN } \\
\text { GEN }\end{array}$ & $\begin{array}{l}1280.9 \\
178.3\end{array}$ \\
\hline Barwon R & $24-26 / 9 / 95$ & $\begin{array}{l}\text { SN } \\
\text { GEN }\end{array}$ & $\begin{array}{l}17.9 \\
0.6\end{array}$ \\
\hline Yarra R & $7-8 / 10 / 95$ & SN & 0 \\
\hline Ansons R & $\begin{array}{l}16- \\
17 / 10 / 95\end{array}$ & GEN & 0 \\
\hline Scamander $\mathrm{R}$ & $\begin{array}{l}14- \\
15 / 10 / 95\end{array}$ & GEN & 0 \\
\hline Swan R & $\begin{array}{l}17- \\
18 / 10 / 95\end{array}$ & GEN & 0 \\
\hline Derwent $R$ & $\begin{array}{l}29 / 9- \\
4 / 10 / 95\end{array}$ & SN & 3.5 \\
\hline Tamar R & $7-13 / 10 / 95$ & $\begin{array}{l}\text { GEN } \\
\text { SN } \\
\text { GEN }\end{array}$ & $\begin{array}{l}1.6 \\
234.5 \\
3.1\end{array}$ \\
\hline
\end{tabular}




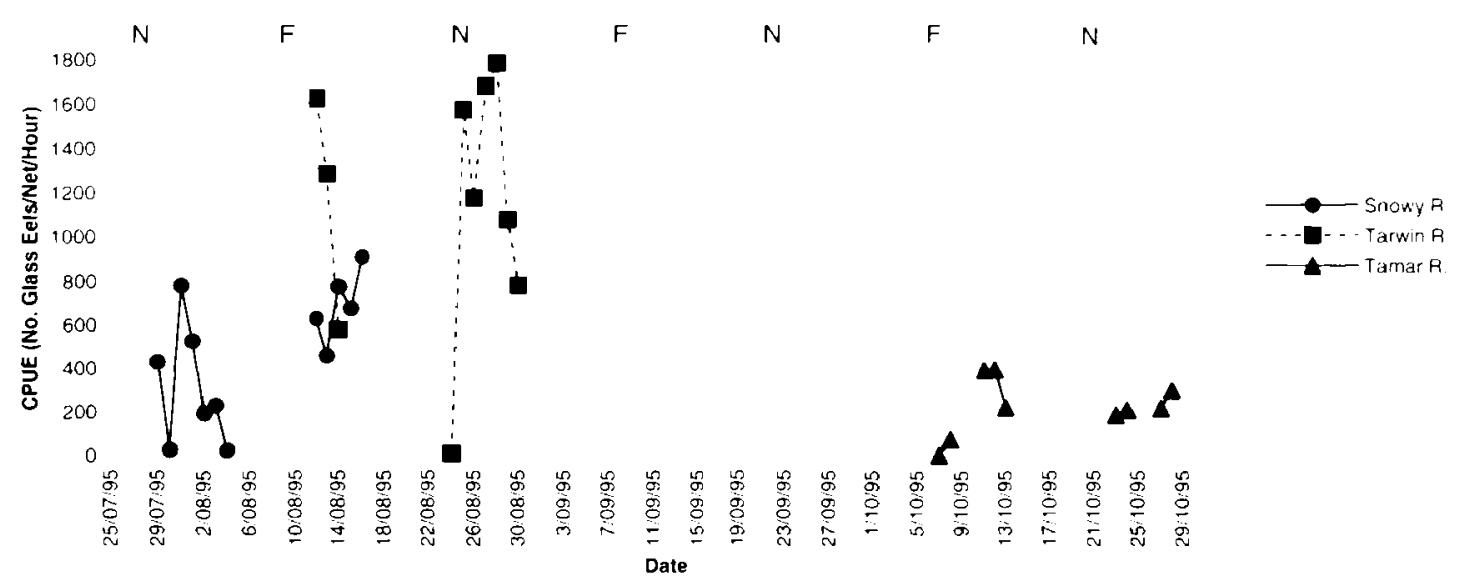

Figure 3

Catch Per Unit Effort (CPUE) of A. australis glass eels in stow nets from three sample sites in 1995. $N=$ new moon, $F=$ full moon.

Figure 3

Captures Par Unité d'Effort (CPUE) de civelles de A. australis dans les filets "hamennet" à partir de trois sites échantillonnés en 1995 . $N=$ nouvelle lune, $F=$ pleine lune.

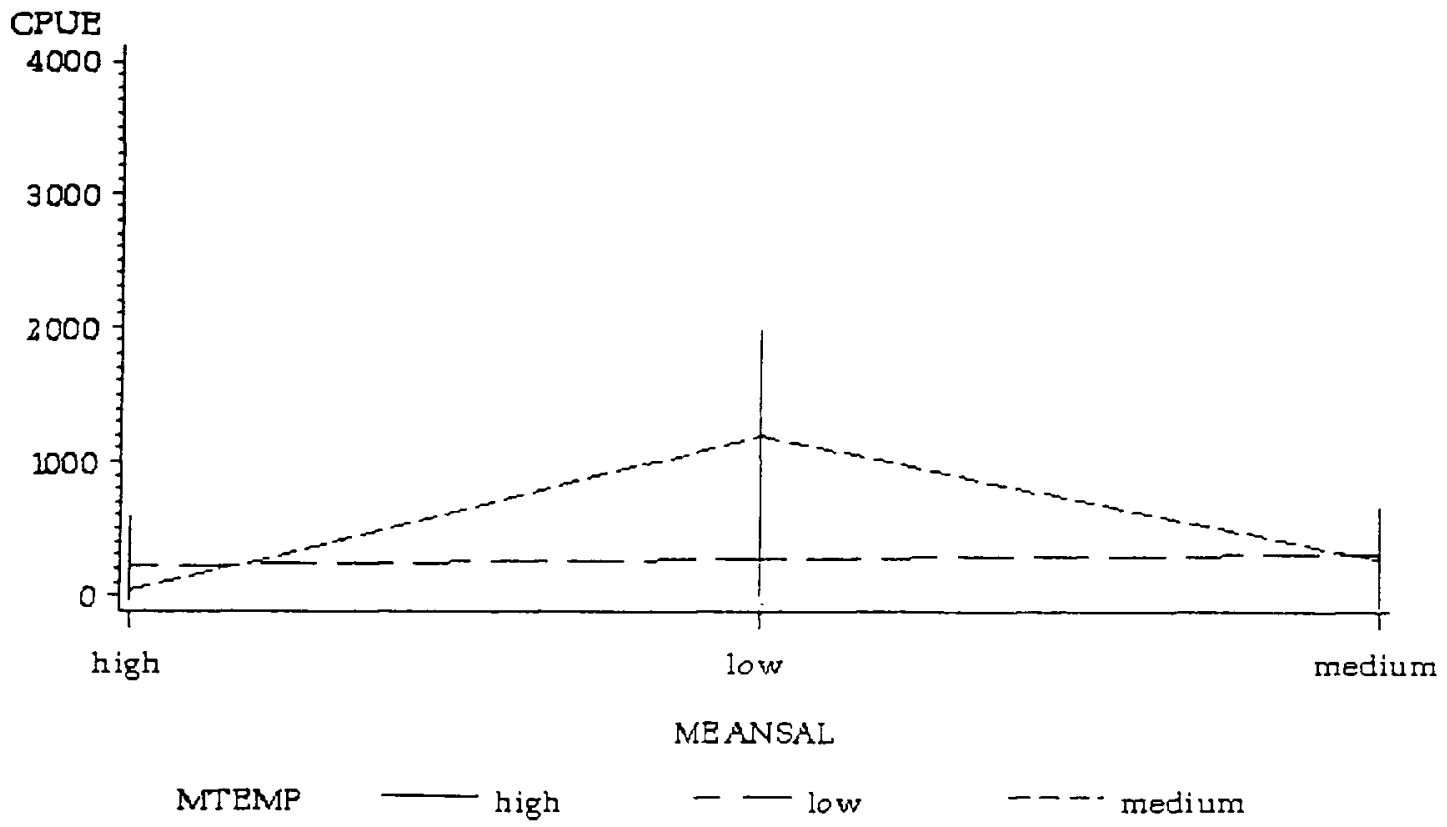



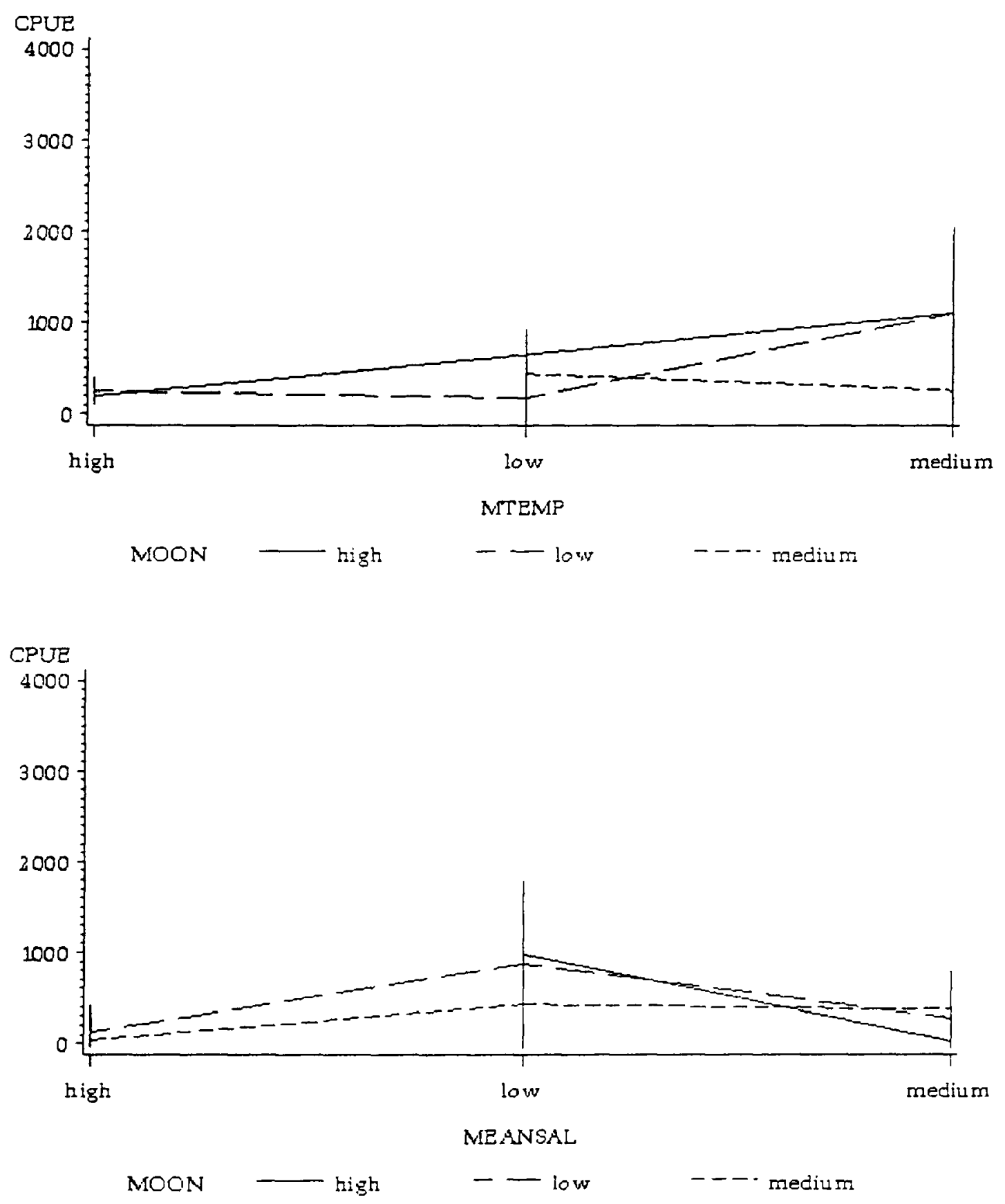

Figure 4

Significant interactions between environmental variables and CPUE for glass eels sampled from the Snowy, Tarwin and Tamar Rivers between 1994 and 1995. "MEANSAL" = mean electrical conductivity, "MTEMP" = mean temperature, "MOON" = moon age, CPUE = No. glass eels/net/hour.

\section{Figure 4}

Interactions significatives entre les variables de l'environnement et les CPUE pour les civelles échantillonnées dans les rivières Snowy, Tarwin et Tamar entre 1994 et 1995. "MEANSAL" = conductivité moyenne, "MTEMP" = température moyenne, "MOON" = phase lunaire (nombre de jours après la nouvelle lune), CPUE = nombre de civelles / filet / heure. 


\section{DISCUSSION - CONCLUSION}

The invasion of $A$. australis glass eels into south-eastern Australian estuaries is highly variable, both spatially and temporally. This level of variability is common in other anguillid eel species (MORIARTY, 1987 ; DOMINGOS, 1992). However, the invasion of glass eels of $A$. australis, and subsequent passive migration via tidal bore, are most common at low salinity (measured as electrical conductivity), and within a specific temperature band in estuarine waters in south-eastern Australia. Indeed, the correlation of these variables with CPUE of glass eels is stronger than that with either lunar phase or height of high tide, which further suggests that such movements may occur during most flood tides, irrespective of lunar phase, provided the water temperature is between 10 and $14^{\circ} \mathrm{C}$. Although lunar phase is important in glass eel migration, with upstream migration of A. australis commencing on the new and full moon and reaching a peak several days later (JELLYMAN, 1979), no direct correlation between lunar cycle, measured as the moon's age in days, and the invasion of glass eels in south-eastern Australian estuaries, could be concluded from the data. However, significant interactions between moon age and temperature and moon age and electrical conductivity were found.

It is likely that the correlation observed between temperature and CPUE is coincidental, as seasonal temperature rises would be expected to occur over the sampling period (late winter-spring) during the period of peak $A$. australis glass eel invasion (BEUMER and HARRINGTON, 1980). However, temperature increases to $10^{\circ} \mathrm{C}$ and above during late winter could still be used as a guide to commence glass eel fishing operations in the study area in order to maximize fishing returns on effort. More specifically, temperature reflects other seasonal changes, of which some may have a more direct influence on glass eel invasion. Likewise, $14^{\circ} \mathrm{C}$ may indicate the upper limit of "effective" fishing.

The correlation found between temperature and CPUE for $A$. australis in the present study is consistent with observations for $A$. anguilla glass eels in which it has been suggested that a preference for freshwater is affected by temperature (TOSI et al., 1990). The initial arrival of incompletely pigmented glass eels of $A$. rostrata at the freshwater interface has been seen to coincide with a large increase in water temperature (SORENSEN and BIANCHINI, 1986), and temperature has been suggested as being more important than time of year in determining the invasion of $A$. anguilla glass eels into estuaries (MORIARTY, 1987). However, other studies have failed to find any correlation between temperature and capture of glass eels of $A$. rostrata (SORENSEN and BIANCHINI, 1986), $A$. anguilla (MORIARTY, 1987) and $A$. australis in New Zealand (JELLYMAN, 1979) during the active migration phase. Therefore, based on these observations and results from the present study, it is suggested that temperature may play a more important part in predicting the initial invasion and passive migration phase of glass eels into estuaries, than in the subsequent active freshwater migration phase within estuaries.

The correlation between electrical conductivity and CPUE may suggest that A. australis glass eels are also attracted to freshwater, as concluded by TOSI et al. (1990) and CHEN, CHEN and TZENG (1994). However, the relationship between electrical conductivity and CPUE in the present study may be somewhat spurious as this variable will generally decrease with distance upstream, as well as with discharge. Although the same sites within streams were sampled during each sampling trip, the distance of the sites from the estuary mouth varied between streams. Thus, while changes in electrical conductivity at each site reflect changes in freshwater discharge, differences between sites may be more likely to reflect differences in distance of each site from the estuary mouth. In aqdition, electrical conductivity is also affected by the magnitude of the flood tide. Higher flood tides can be expected to penetrate further upstream, thus creating more saline conditions for longer periods of time during the tidal cycle at any given location in the estuary. 
Although height of high tide showed a positive correlation with CPUE in the present study, interaction with the other variables was not significant. Glass eel sampling was conducted generally between 2-3 days before and 2-3 days after new and full moons, but not during the intervening periods. Sampling over the complete lunar/tidal cycle therefore did not occur, thus lunar/tidal effects cannot be discounted as influencing the invasion of A. australis glass eels.

In conclusion, temperature and salinity were found to be important environmental criteria in determining when peak invasion periods of $A$. australis glass eels are likely to occur in south-eastern Australian estuaries. This information is useful in determining optimal periods for glass eel fishing, which may therefore assist in the development of a commercial glass eel fishery in Australia.

\section{ACKNOWLEDGEMENTS}

The authors wish to thank Richard GASIOR for assistance with data collection, Anne GASON for the statistical analyses and Aline BRUSSESE for the French translations.

\section{REFERENCES}

ANTUNES C., 1994. The seasonal occurrence of glass eels (Anguilla anguilla L.) in the Rio Minho between 1991 and 1993 (North of Portugal). Int. Revue ges. Hydrobiol., 79 (2), 287-294.

ANTUNES C., WEBER M., 1993. The glass eel fishery and the by-catch in the Rio Minho after one decade (1981-1982 and 1991-1992). EIFAC Working Party on Eel, Olsztyn, Poland, May 1993, 12 p.

BEUMER J.P., 1983a. Suitability of Anguilla australis for intensive culture. Austasia Aquaculture, 4, 13-18.

BEUMER J.P., 1983b. Eels. Victorian Naturalist, 100 (4), 168-171.

BEUMER J.P., HARRINGTON D.J., 1980. Techniques for collecting glass eels and brown elvers. Australian Fisheries, 39 (8), 16-22.

BEUMER J., SLOANE R., 1990. Distribution and abundance of glass eels Anguilla spp. in east Australian waters. Int. Revue ges. Hydrobiol., 75 (6), 721-736.

CHEN Y.L., CHEN H.Y., TZENG W.N., 1994. Reappraisal of the importance of rainfall in affecting catches of Anguilla japonica elvers in Taiwan. Australian Journal of Marine and Freshwater Research, 45, 185-190.

CREUTZBERG F., 1961. On the orientation of migrating elvers (Anguilla vulgaris Turt.) in a tidal area. Netherlands Journal of Sea Research, 1, 257-388.

DEELDER C.L., 1970. Synopsis of biological data on the eel Anguilla anguilla (Linnaeus) 1758. FAO Fisheries Synopsis No. 80, $71 \mathrm{p}$.

DOMINGOS I.M., 1992. Fluctuation of glass eel migration in the Mondego estuary (Portugal) in 1988 and 1989. Irish Fisheries Investigations, Series A (Freshwater), 36, 1-4.

GASCUEL D., 1986. Flow-carried and active swimming migration of the glass eel (Anguilla anguilla) in the tidal area of a small estuary on the French Atlantic coast. Helgoländer Meeresunters, 40, 321-326.

GUERAULT D., PROUZET P., DESAUNAY Y., BEILLOIS P., 1991. The recent evolution of the glass eel immigration in three French Atlantic estuaries. EIFAC Working Party on Eel, Dublin, Ireland, May 1991. 
JELLYMAN D.J., 1977. Invasion of a New Zealand freshwater stream by glass eels of two Anguilla spp. New Zealand Journal of Marine and Freshwater Research, 11 (2), 193-209.

JELLYMAN D.J., 1979. Upstream migration of glass eels (Anguilla spp.) in the Waikato River. New Zealand Journal of Marine and Freshwater Research, 13 (1), 13-22.

MCCLEAVE J.D., KLECKNER R.C., 1982. Selective tidal stream transport in the estuarine migration of glass eels of the American eel (Anguilla rostrata). Journal du Conseil International pour l'Exploration de la Mer, 40, 262-271.

MCCLEAVE J.D., WIPPELHAUSER G.S., 1987. Behavioural aspects of selective tidal stream transport in juvenile American eels. American Fisheries Society Symposium, 1, 138-150.

MCCLEAVE J.D., BEDAUX J.J.M., DOUCET P.G., JAGER J.C., JONG J.T.L., VAN DER STEEN W.J., VOORZANGER B., 1987. Statistical methods for analysis of plankton and nekton distribution, with application to selective tidal stream transport of juvenile American eels (Anguilla rostrata). Journal du Conseil International pour l'Exploration de la Mer, 44, 90-103.

MORIARTY C., 1987. Factors influencing recruitment of the Atlantic species of anguillid eels. American Fisheries Society Symposium, 1, 483-491.

MORIARTY C., 1992. Catches of Anguilla anguilla elver on the Atlantic coast of Europe, 1989-1990. Irish Investigations, Series A (Freshwater), 36, p 33.

SLOANE R.D., 1984. Invasion and upstream migration by glass eels of Anguilla australis australis Richardson and $A$. reinhardtii Steindachner in Tasmanian freshwater streams. Australian Journal of Marine and Freshwater Research, 35, 47-59.

SOLA C., 1995. Chemoattraction of upstream migrating glass eels Anguilla anguilla to earthy and green odorants. Environmental Biology of Fishes, 43, 179-185.

SOLA C., TONGIORGI P., 1996. The effect of salinity on the chemotaxis of glass eels, Anguilla anguilla, to organic earthy and green odorants. Environmental Biology of Fishes, 47, 213-218.

SORENSEN P.W., 1986. Origins of the freshwater attractant(s) of migrating elvers of the American eel, Anguilla rostrata. Environmental Biology of Fishes, 17 (3), 185-200.

SORENSEN P.W., BIANCHINI M.L., 1986. Environmental correlates of the freshwater migration of elvers of the American eel in a Rhode Island brook. Transactions of the American Fisheries Society, 115, 258-268.

TESCH F.W., 1977. The Eel. Biology and Management of Anguillid Eels. Chapman and Hall, London, $434 \mathrm{p}$.

TONGIORGI P., TOSI L., BALSAMO M., 1986. Thermal preferences in upstream migrating glass-eels of Anguilla anguilla (L.). Journal of Fish Biology, 28, 501-510.

TOSI L., SPAMPANATO A., SOLA C., TONGIORGI P., 1990. Relation of water odour, salinity and temperature to ascent of glass eels, Anguilla anguilla (L.) : a laboratory study. Journal of Fish Biology, 36, 327-340.

WEBER M., 1986. Fishing method and seasonal occurrence of glasseels (Anguilla anguilla L.) in the Rio Minho, west coast of the Iberian Peninsula. Vie Milieu, 36 (4), 243250. 